\title{
Trace element accumulation in plants from an aridic area affected by mining activities
}

\author{
María José Martínez-Sánchez ${ }^{\mathrm{a}}$, Mari Luz García-Lorenzo ${ }^{\mathrm{b}}$, Carmen Pérez-Sirvent ${ }^{\mathrm{a}}$ *, Jaume Bech ${ }^{\mathrm{c}}$ \\ a Department of Agricultural Chemistry, Geology and Pedology, Faculty of Chemistry, University of Murcia, Spain \\ ${ }^{\mathrm{b}}$ Department of Petrology and Geochemistry, Faculty of Geology, Complutense University of Madrid, Spain \\ ${ }^{\mathrm{c}}$ Department of Plant Biology, Faculty of Biology, University of Barcelona, Spain
}

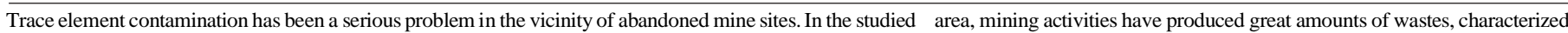

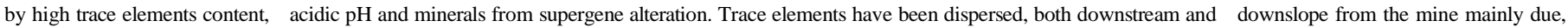

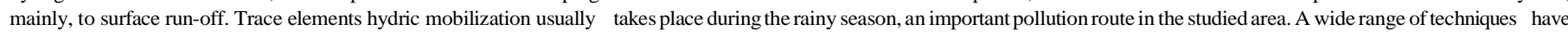

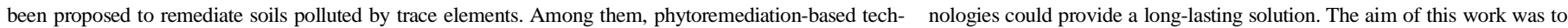

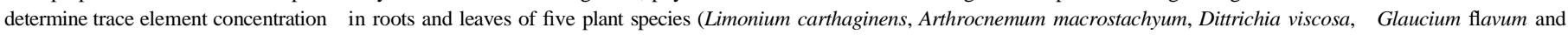

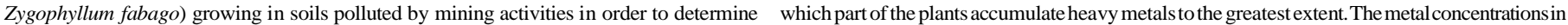

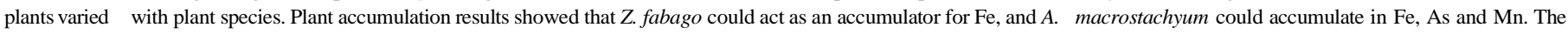
other plant species collected from the mining sites were tolerant to trace element contamination.

Keywords: Trace Elements

Accumulator

Phytoremediation Translocationfactor Soil contamination

\section{Introduction}

Mining activities generate a large amount of tailings that are gen- erally deposited upon the soil surface. Tailings usually provide an un- favorable substrate for plant growth because of their low $\mathrm{pH}$, high concentrations of trace elements and low nutrient content (Ha et al., 2011). Specifically, metalliferous mining and processing, including the dumping of wastes, often produce severe trace element pollution (Baker et al., 1994). Soils contaminated with trace elements usually lack established vegetation cover, either due to the toxic effects of pollutants or due to physical disturbance (Rotkittikhun et al., 2006). The contamination of soils due to the presence of toxic elements could result in negative consequences, such as damage of ecosystems and of agricultural productivity, deterioration of food chain, contam- ination of water resources, economic damage and serious human and animal health problems.

A wide range of techniques have been proposed to remediate soils polluted by trace elements. Soil clean-up technologies are often expen- sive, energy consuming and usually soil can rarely be used after the treatment. Some methods, however, may be considered a cost- effective solution for treating soils polluted by trace elements, and among them, phytoremediation-based technologies, may well provide a long-lasting solution, since they use plants to stabilize pollutants

\footnotetext{
* Corresponding author. Tel.: +34868887449; fax: +34868884148.

E-mail address: melita@um.es (C. Pérez-Sirvent).
}

from soils (Gardea-Torresdey et al., 1996; Hernández-Allica et al., 2006; Zhuang et al., 2005). Phytoremediation can be defined as the use of plants for containment, degradation or extraction of xenobiotics from water or soil substrates (USEPA, 2000).

The presence of vegetation reduces water and wind erosion, which may decrease the downward migration of contaminants into the groundwater. Furthermore, tolerant plants can help in the physical and chemical immobilisation of contaminants through root sorption or by inducing chemical retention in the soil (Prasad and Freitas, 2003). The best plants for phytoremediation purposes are native plants because of their greater chance of survival, growth and repro- duction in environmental stress conditions than plants introduced from other environments (Adriano, 2001; Antonsiewicz et al., 2008).

There are several distinct groups of plant species according to their trace element accumulation capability (Baker, 1981): (a) ex- cluders, which metal concentrations in the shoots are maintained at a low level up to a critical value across a wide range of soil concentra- tions; b) accumulators, in which metals are concentrated in above- ground plant parts from low to great soil concentrations; and c) indicators, in which the internal concentration reflects external levels. A particular sub-group within the accumulators is represented by the hyperaccumulators (Adriano, 2001; Brooks et al., 1977). Hyperaccumulators are plants commonly grown on metalliferous soils and able to complete their life cycle without any symptoms of metal phytotoxicity (Baker et al., 2000). The criteria to define hyper- accumulation for arsenic, lead, cobalt, copper and selenium are a 
concentration of $1000 \mathrm{mg} \mathrm{kg}^{-1}$ or greater, on a dry leaf basis, where- as the threshold value for zinc and manganese hyperaccumulation is $10000 \mathrm{mg} \mathrm{kg}^{-1}$ (Baker and Brooks, 1989; Kabata-Pendias and Mukherjee, 2007). Cadmium hyperaccumulators are defined as values larger or equal to $100 \mathrm{mg} \mathrm{kg}^{-1}$. Hyperaccumulators could be characterized by a shoot-to-root metal concentration ratio (transloca- tion factor, TF) of more than 1 , whereas nonhyperaccumulator plants usually have greater metal concentrations in the roots than in the shoots. Several authors (Baker, 1981; Baker et al., 1994; Bech et al., 2012; McGrath and Zhao, 2003; Sun et al., 2008) included the bioac- cumulation factor (BCF) as an element for classification as a hyperaccumulator species. The BCF refers to the plant metal concentration and the soil metal concentration ratio. A BCF value higher than 1 may be taken to indicate that the plant could act as a hyperaccumula- tor of trace elements.

The aim of this work was to determine the trace element concen- tration in roots and leaves of plant species growing in soils polluted by mining activities, in order to determine which part of the plants accumulate trace elements to the greatest extent. In addition, the study was carried out to compare the trace element accumulation capacity of selected plant species growing on contaminated soils and to assess changes in the concentration of soil-available metals. Five plant species (Limonium carthaginens, Arthrocnemum macrosta- chyum, Dittrichia viscosa, Glaucium flavum and Zygophyllum fabago) were studied, and the transfer factor (TF) and the bioconcentration factor(BCF) were calculated.

\section{Materialsandmethods}

\subsection{Study area and sample collection}

The studied area is located in the southeast of Murcia Region (Spain). It is a coastal mountain chain with an approximate extension of $50 \mathrm{~km}^{2}$. This zone was one of the main mining districts in the southeast of Spain (Martínez-Sánchez et al., 2008).

The annual average temperature is $17{ }^{\circ} \mathrm{C}$ and precipitation does not exceed $300 \mathrm{~mm}$, with occasional torrential rainfall which normal- ly occurs between the end of summer and autumn. Perennial streams do not exist, and surface water consists of ephemeral streams, which are only operational during rainfall events. The stream flow is flashy and a significant amount of sediments are transported after long- lasting rainfalls.

As a result of mining activities, the studied area shows a large number of contaminations sources, formed by mining steriles, waste piles and foundry residues. The extractive activity has resulted in var- iations in the drainage network with modification of natural slopes, and favouring erosion processes, increased by the scarce vegetation present (García-Lorenzo et al., 2012).
For this study, 15 sediment samples were collected. Sampling was carried out in an area where the dispersion of trace elements and their zone of influence are being studied and where it had been ob- served that spontaneous revegetation had occurred in zones that had been affected by mining activity.

In addition to sediments, samples of five plant species, which nat- urally grow in this area, (L. carthaginens, A. macrostachyum, D. viscosa,

G. flavum and Z. fabago) were collected. In some of the sampling points Artrocnemum macrostachyum and $L$. carthaginens were not studied because of their specific requirements. In total, 15 samples of $D$. viscosa, G. flavum and Z. fabago, 10 of $L$. carthaginens and 5 of Artrocnemum macrostachyum were collected. D. viscosa, Z. fabago and $L$. carthaginens usually grow in semiarid areas because of their low nutritional needs. They are resistant and perennial. Artrocnemum macrostachyum shows similar behaviour to the above species but usually grows in wet areas. It is saltresistant, grows slowly and sometimes forms groups. The main characteristic of $G$. flavum is its short life cycle.

\subsection{Sample preparation and chemical analysis}

Superficial sediment samples $(0-10 \mathrm{~cm})$ were collected from four subsampling points in a circle about $50 \mathrm{~cm}$ around the plant species and homogenised. Homogenized samples were air-dried at room temperature and sieved through a $2 \mathrm{~mm}$ screen for general analytical determinations.

The $\mathrm{pH}$ was measured in a 1:5 suspension of soil in high quality water obtained by means of a Milli-Q system. Electrical conductivity (EC) $\left(\mathrm{dS} \mathrm{m}^{-1}\right.$ at $25^{\circ} \mathrm{C}$ ) was measured in the extracts obtained by filter- ing the 1:5 suspensions through a $0.45 \mu \mathrm{m}$ cellulose acetate disk filter. Equivalent calcium carbonate (\%) was determined by the volumetric method using a Bernard calcimeter. Organic carbon was determined by sulfochromic oxidation (Nelson and Sommers, 1982), according to theNFX31-109 standard(AFNOR, 1993).

A semiquantitative estimation of the mineralogical composition of the samples was made by X-ray Diffraction (XRD) analysis using $\mathrm{Cu}-\mathrm{K} \alpha$ radiation with a PW3040 Philips Diffractometer. X-powder software (Martín, 2004) was used to analyse the X-ray diffraction diagrams obtained by the crystalline powder method. The powder diffraction file (PDF2) database was used for peak identification, taking into account that the determination of minerals from soils by XRD analysis is not accu- rate below a limit of $5 \%$ of the total weight in a sample (depending on the crystallinity of individual minerals).

To determine the total trace element content, the sediments were first ground to a fine powder using a zirconium ball mill. Aliquots $(0.1 \mathrm{~g})$ of sediment samples were placed in Teflon vessels and $5 \mathrm{ml}$ of concentrated $\mathrm{HF}$ acid solution, $200 \mu \mathrm{l}$ of concentrated $\mathrm{HNO}_{3}$ acid solution and $5 \mathrm{ml}$ of water were added. When digestion in the

Table 1

Analytical characteristics in sediment samples.

\begin{tabular}{|c|c|c|c|c|c|c|c|c|c|c|c|}
\hline Sample & $\mathrm{pH}$ & $\mathrm{EC}\left(\mathrm{dS} \mathrm{m} \mathrm{m}^{-1}\right)$ & $\mathrm{CaCO}_{3}(\%)$ & OM (\%) & $\mathrm{Zn}\left(\mathrm{mg} \mathrm{kg}^{-1}\right)$ & $\mathrm{Pb}\left(\mathrm{mg} \mathrm{kg}^{-1}\right)$ & $\mathrm{Cd}\left(\mathrm{mg} \mathrm{kg}^{-1}\right)$ & $\mathrm{Fe}(\%)$ & As $\left(\mathrm{mg} \mathrm{kg}^{-1}\right)$ & $\mathrm{Cu}\left(\mathrm{mg} \mathrm{kg}^{-1}\right)$ & $\operatorname{Mn}\left(\mathrm{mg} \mathrm{kg}^{-1}\right)$ \\
\hline $\mathrm{S} 1$ & 8.6 & 1.4 & 15.3 & 1.6 & 5455 & 2130 & 42.1 & 6.49 & 1235 & 299 & 1992 \\
\hline S2 & 5.0 & 7.4 & bdl & bdl & 8984 & 3989 & 88.3 & 25.14 & 752 & 142 & 4053 \\
\hline S3 & 7.4 & 2.8 & 10.1 & bdl & 3153 & 1241 & 123.1 & 26.11 & 669 & 123 & 3498 \\
\hline $\mathrm{S} 4$ & 7.8 & 2.9 & 1.0 & bdl & 7958 & 3621 & 34.3 & 19.23 & 454 & 124 & 3537 \\
\hline S5 & 6.9 & 1.4 & 1.0 & 1.0 & 7062 & 4741 & 19.1 & 24.53 & 561 & 127 & 3767 \\
\hline S6 & 6.6 & 1.7 & 1.3 & bdl & 7239 & 6757 & 20.4 & 24.23 & 530 & 145 & 3378 \\
\hline S7 & 5.3 & 0.5 & bdl & 1.3 & 4000 & 13500 & 15.1 & 19.25 & 644 & 185 & 1390 \\
\hline $\mathrm{S} 8$ & 4.2 & 2.5 & bdl & 1.0 & 2388 & 554 & 10.7 & 4.29 & 3115 & 110 & 6686 \\
\hline S9 & 8.1 & 0.5 & 13.3 & 1.2 & 1210 & 1936 & 11.2 & 7.30 & 304 & 131 & 1447 \\
\hline $\mathrm{S} 10$ & 7.5 & 0.2 & bdl & bdl & 6398 & 709 & 65.5 & 38.59 & 554 & 68 & 8350 \\
\hline S11 & 7.4 & 3.5 & bdl & bdl & 6600 & 1003 & 74.3 & 50.58 & 868 & 147 & 10806 \\
\hline $\mathrm{S} 12$ & 7.5 & 0.2 & 1.2 & bld & 135 & 63 & 6.3 & 16.11 & 40 & 171 & 864 \\
\hline $\mathrm{S} 13$ & 7.9 & 0.4 & 28.7 & 0.5 & 1494 & 538 & 12.1 & 4.63 & 327 & 129 & 1584 \\
\hline $\mathrm{S} 14$ & 7.7 & 0.7 & bld & 1.3 & 3670 & 2041 & 14.8 & 11.83 & 563 & 119 & 1528 \\
\hline S15 & 7.5 & 0.5 & 4.9 & 0.7 & 3049 & 3002 & 14.5 & 18.99 & 664 & 150 & 1735 \\
\hline
\end{tabular}


Table 2

Average mineralogical composition (\%) of the sediment samples in the study area.

\begin{tabular}{|c|c|c|c|c|c|c|c|c|c|c|c|c|c|}
\hline Sample & Phy & Fsp & Qtz & Gp & Jar & Hem & Gt & Cal & Dol & Aka & Sid & Gol & $\mathrm{Am}$ \\
\hline $\mathrm{S} 1$ & 27 & 44 & 6 & & 18 & 5 & & & & & & & 1 \\
\hline S2 & 35 & 2 & 28 & 9 & 10 & 6 & & & & 11 & & & 1 \\
\hline S3 & 28 & 2 & 29 & & 6 & 7 & & 14 & & 12 & & & 2 \\
\hline S4 & 13 & 3 & 34 & 13 & 8 & 3 & & 6 & & 14 & & 4 & 2 \\
\hline S5 & 12 & 4 & 30 & 14 & 11 & 2 & 4 & & & 14 & & 6 & 3 \\
\hline S6 & 15 & 2 & 33 & 9 & 11 & 3 & 6 & & & 12 & & 7 & 2 \\
\hline S7 & 15 & 2 & 32 & 7 & 14 & 4 & 8 & & & 11 & & 6 & 2 \\
\hline S8 & 3 & 5 & 34 & 32 & 11 & 2 & & & & 13 & & & 1 \\
\hline S9 & 30 & 13 & 39 & & & 9 & & & & 7 & & & 2 \\
\hline S10 & 31 & & 15 & 7 & 9 & 5 & & & & 8 & 22 & & 3 \\
\hline S11 & 20 & & 9 & 4 & 6 & 9 & & & & 1 & 42 & & 1 \\
\hline $\mathrm{S} 12$ & 3 & & 3 & & & & & 2 & 89 & & & & 3 \\
\hline S13 & 28 & 7 & 40 & & & & & 16 & 7 & & & & 3 \\
\hline S14 & 53 & 7 & 22 & & & 7 & & & & & & 8 & 2 \\
\hline S15 & 30 & 5 & 47 & & & 4 & & 11 & & & & & 4 \\
\hline
\end{tabular}

Phy: Phylosilicates; Fsp: Feldspars; Qtz: Quartz; Jar: Jarosite; Gt: Goethite; Aka: Akaganeite; Cal: Calcite; Dol: Dolomite; Gol: Goldichite; Gp: Gypsum; Hem: Hematite; Sid: Siderite; Am: Amorphous.

microwave oven was complete, the solutions were transferred to a volumetric flask and brought to $50 \mathrm{ml}$.

Fresh vegetable samples were separated into root and aboveground biomass and then lyophilized. $200 \mathrm{mg}$ of lyophilized vegetal tissue was placed in Teflon vessels with $3 \mathrm{ml}$ of water, $2 \mathrm{ml}$ of concentrated $\mathrm{H}_{2} \mathrm{O}_{2}$ and $5 \mathrm{ml}$ of concentrated $\mathrm{HNO}_{3}$ acid solution. When digestion in the mi- crowave oven was complete, the solutions were transferred to a volu- metric flask and brought to $50 \mathrm{ml}$.

The zinc, iron and manganese content was determined by flame atomic absorption spectrometry (FAAS) using a Perkin-Elmer 1100B Atomic Absorption Spectrophotometer. The lead, cadmium and copper content was determined by electrothermal atomization atomic absorp- tion spectrometry (ETAAS) using a Unicam 929 AAS spectrometer. The arsenic content was measured by atomic fluorescence spectrometry using an automated continuous flow hydride generation spectrometer (PSA Millenium Merlin 10055 for arsenic). The reliability of the results was verified by analysing a standard reference material (SRM 2711 Montana Soil, NCS DC 73320 and NCS DC 73323 for soil samples and SRM 1515 Apple leaves and SRM 1572 Citrus leaves for plant samples). Spikes, duplicates and reagent blanks were also used as part of quality assurance/qualitycontrol.

Bioconcentration factor (BCF) and translocation factor (TF) are im- portant parameters in heavy metal uptake studies (Marchiol et al., 2004; Bose et al., 2008). In order to evaluate the phytoextraction poten- tial of the selected plants, the bioconcentration factor $\left(\mathrm{BCF}=\mathrm{C}_{\text {roots }} / \mathrm{C}_{\text {soil }}\right)$ and the translocation factor $\left(\mathrm{TF}=\mathrm{C}_{\text {leaves }} / \mathrm{C}_{\text {roots }}\right)$, where $\mathrm{C}$ represents the metal concentration, were calculated.

\section{Results and discussion}

\subsection{Soil properties and metal concentrations}

The general characteristics of the soil samples are given in Table 1. Most samples showed neutral $\mathrm{pH}$ values, with an average value of 7.1, although S2, S7 and $\mathrm{S} 8$ showed acidic $\mathrm{pH}$ values. All the samples pre- sented a very low organic matter percentage (mean value of $0.8 \%$ ), low soluble salt content and low calcium carbonate percentage. The average value for calcium carbonate was $9.7 \%$ and the highest value was $28.7 \%$, in S13. The average value for $\mathrm{Zn}$ was $4586 \mathrm{mg} \mathrm{kg}^{-1}$, $3073 \mathrm{mg} \mathrm{kg}^{-1}$ for lead, $40 \mathrm{mg} \mathrm{kg}^{-1}$ for cadmium, $19 \%$ of iron,

$806 \mathrm{mg} \mathrm{kg}^{-1}$ for arsenic, $129 \mathrm{mg} \mathrm{kg}^{-1}$ for copper and $3566 \mathrm{mg} \mathrm{kg}^{-1}$ formanganese.

The plant species selected grew in poorly developed soils formed by materials from surrounding mining areas, carbonate materials and phyllites. The mineralogical analysis showed that the main min- erals were quartz and phyllosilicates, while the minority minerals were products of mining activities (iron oxides and hydroxides, siderite, jarosite and gypsum), calcite and feldspars (Table 2).

Fig. 1 summarises the conceptual model of main processes affect- ing materials in areas with mining influence in the studied area. The most important weathering processes in the studied area are oxidation-reduction, hydration, hydrolysis and dissolution-precipitation. In the studied sediments, mining activities have produced intense mor- phological changes, modifying drainage network and natural slopes, taking place remontant erosion processes. In addition, torrential rainfall and the scant vegetation present in the studied area amplify the erosive process (Fig. 2). During the transport phase, dissolution and hydration processes acquire more importance and weathering products are mobilized as dissolved or particulate phases. When kinetic energy of the sys- tem diminishes, sedimentation processes happen. Dissolved and particulate materials are deposited, taking place heterogeneous chemi- cal reactions (GarcíaLorenzo et al., 2012).

\subsection{Metal concentration in plants and bioconcentration and translocation factor determination}

Table 3 summarises the average trace element content in roots and leaves of selected species and Table 4 showed the bioconcentra- tion (BCF) and translocation (TF) factor results for collected samples. In L. carthaginens and $Z$. fabago leave concentration was lower than root concentration. Since all samples showed BCF and TF lower than unity, these species could be considered as tolerant.
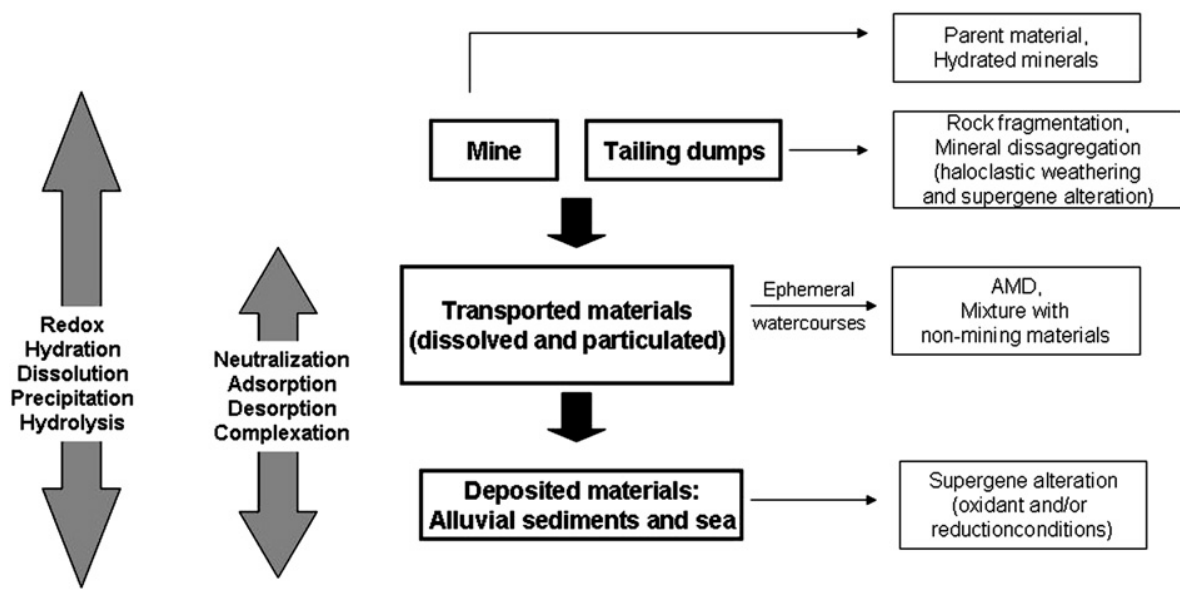

Fig. 1. Main processes affecting materials in areas with mining influence. 

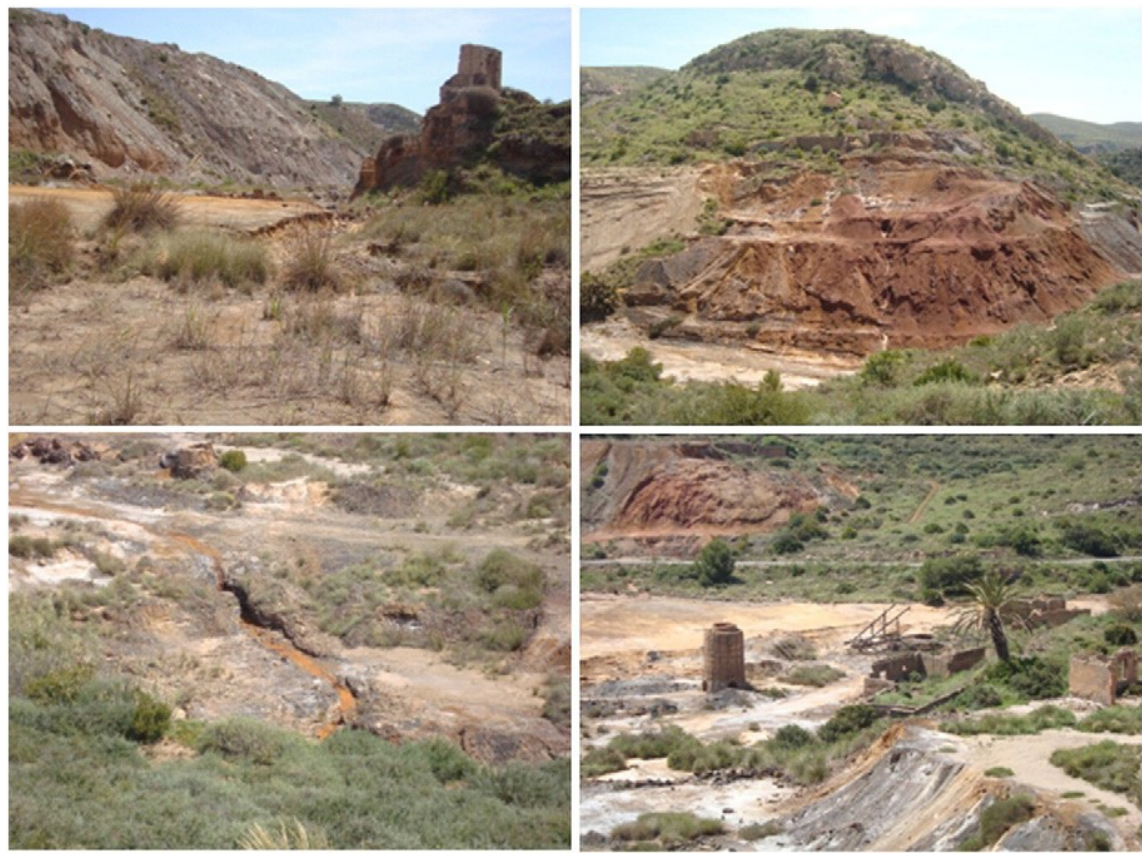

Fig. 2. Pictures of the studied area.

Iron content in leaves of $G$. flavum was higher than those found in roots of this species. For the other elements, trace element content was higher in roots. BCF was lower than unity for all the studied ele- ments in all samples, while TF was higher than unity for iron. G. flavum seems to have a higher capacity for iron translocation from roots to shoots.

In Artrocnemum macrostachyum, BCF was higher than unity for zinc and cadmium, showing that $A$. macrostachyum seems to have higher ca- pacity for zinc and cadmium absorption from soil to roots. In addition, arsenic, manganese and iron have been translocated to the aerial bio- mass (TF value higher than unity).
Finally, D. viscosa showed higher concentrations in leaves than in roots for $\mathrm{Pb}$ and iron. For the other elements root concentration was higher than leaves concentration. BCF in this species was lower than unity for all the studied elements, and this species could be consid- ered as a tolerant plant for all the studied elements.

\section{Conclusions}

The studied area is strongly affected by mining activities, and su- perficial materials have suffered weathering processes, releasing a great amount of trace elements and sulphates, which are transported

Table 3

Mean trace element content in roots and leaves $\left(\mathrm{mg} \mathrm{kg}^{-1}\right)$ of selected species ( \pm standard deviation).

\begin{tabular}{|c|c|c|c|c|c|c|c|}
\hline & \multicolumn{7}{|c|}{ Limonium carthaginens } \\
\hline & $\mathrm{Zn}$ & $\mathrm{Pb}$ & $\mathrm{Cd}$ & $\mathrm{Fe}$ & As & $\mathrm{Cu}$ & Mn \\
\hline Roots & $392 \pm 27$ & $138 \pm 5$ & $2.9 \pm 0.8$ & $909 \pm 51$ & $8.4 \pm 1.1$ & $11.1 \pm 0.3$ & $75.1 \pm 1.7$ \\
\hline \multirow[t]{3}{*}{ Leaves } & $297 \pm 22$ & $107 \pm 7$ & $2.4 \pm 0.4$ & $807 \pm 32$ & $2.7 \pm 0.5$ & $8.1 \pm 0.6$ & $28.6 \pm 0.4$ \\
\hline & \multicolumn{7}{|c|}{ Glaucium flavum } \\
\hline & $\mathrm{Zn}$ & $\mathrm{Pb}$ & $\mathrm{Cd}$ & $\mathrm{Fe}$ & As & $\mathrm{Cu}$ & $\mathrm{Mn}$ \\
\hline Roots & $1406 \pm 38$ & $1232 \pm 21$ & $7.6 \pm 2.2$ & $241 \pm 24$ & $42.8 \pm 1.6$ & $25.1 \pm 2.2$ & $296.9 \pm 41.8$ \\
\hline \multirow[t]{3}{*}{ Leaves } & $289 \pm 16$ & $147 \pm 33$ & $7.3 \pm 2.1$ & $275 \pm 14$ & $2.8 \pm 0.4$ & $18.0 \pm 1.5$ & $83.8 \pm 12.3$ \\
\hline & \multicolumn{7}{|c|}{ Artrocnemum macrostachyum } \\
\hline & $\mathrm{Zn}$ & $\mathrm{Pb}$ & $\mathrm{Cd}$ & $\mathrm{Fe}$ & As & $\mathrm{Cu}$ & $\mathrm{Mn}$ \\
\hline Roots & $4893 \pm 45$ & $743 \pm 24$ & $24.4 \pm 2.4$ & $9499 \pm 44$ & $97.4 \pm 8.3$ & $70.2 \pm 1.3$ & $597.4 \pm 1.6$ \\
\hline \multirow[t]{3}{*}{ Leaves } & $1649 \pm 13$ & $724 \pm 9$ & $3.4 \pm 0.7$ & $18822 \pm 21$ & $101.0 \pm 3.3$ & $19.9 \pm 0.8$ & $1893.4 \pm 1.4$ \\
\hline & \multicolumn{7}{|c|}{ Zygophyllum fabago } \\
\hline & $\mathrm{Zn}$ & $\mathrm{Pb}$ & $\mathrm{Cd}$ & $\mathrm{Fe}$ & As & $\mathrm{Cu}$ & $\mathrm{Mn}$ \\
\hline Roots & $114 \pm 2.3$ & $3.8 \pm 0.4$ & $18.2 \pm 3.3$ & $1600 \pm 29,6$ & $15.1 \pm 2.3$ & $24.7 \pm 4.6$ & $113.8 \pm 1.3$ \\
\hline \multirow[t]{3}{*}{ Leaves } & $47 \pm 1.1$ & $3.1 \pm 0.6$ & $32.4 \pm 2.1$ & $2000 \pm 50,7$ & $11.8 \pm 1.3$ & $35.8 \pm 0.7$ & $47.4 \pm 2.2$ \\
\hline & \multicolumn{7}{|c|}{ Dittrichia viscosa } \\
\hline & $\mathrm{Zn}$ & $\mathrm{Pb}$ & $\mathrm{Cd}$ & $\mathrm{Fe}$ & As & $\mathrm{Cu}$ & $\mathrm{Mn}$ \\
\hline Roots & $446 \pm 2.2$ & $25 \pm 1.4$ & $33.7 \pm 0.8$ & $37 \pm 2.2$ & $21.7 \pm 0.6$ & $53.9 \pm 0.2$ & $445.6 \pm 0.9$ \\
\hline Leaves & $187 \pm 1.2$ & $187 \pm 1.1$ & $3.9 \pm 0.6$ & $1119 \pm 15.7$ & $13.6 \pm 0.3$ & $14.8 \pm 0.3$ & $65.2 \pm 0.3$ \\
\hline
\end{tabular}


Bioconcentration factor(BCF) and translocation factor(TF)averagevalue in selectedplant species ( \pm standard deviation).

\begin{tabular}{|c|c|c|c|c|c|c|c|c|c|c|}
\hline & \multicolumn{2}{|c|}{ Limonium carthaginens } & \multicolumn{2}{|c|}{ Glaucium flavum } & \multicolumn{2}{|c|}{$\begin{array}{l}\text { Artrocnemum } \\
\text { macrostachyum }\end{array}$} & \multicolumn{2}{|c|}{ Zygophyllum fabago } & \multicolumn{2}{|c|}{ Dittrichia viscosa } \\
\hline & BCF & TF & BCF & $\mathrm{TF}$ & BCF & $\mathrm{TF}$ & BCF & $\mathrm{TF}$ & BCF & $\mathrm{TF}$ \\
\hline Zn & $0.05 \pm 0.02$ & $0.71 \pm 0.11$ & $0.48 \pm 0.02$ & $0.53 \pm 0.02$ & $1.01 \pm 0.24$ & $0.22 \pm 0.08$ & $0.23 \pm 0.16$ & $0.62 \pm 0.09$ & $0.33 \pm 0.19$ & $0.45 \pm 0.11$ \\
\hline $\mathrm{Pb}$ & $0.05 \pm 0.03$ & $0.78 \pm 0.02$ & $0.35 \pm 0.09$ & $0.50 \pm 0.13$ & $0.47 \pm 0.16$ & $0.88 \pm 0.17$ & $0.05 \pm 0.02$ & $0.50 \pm 0.12$ & $0.48 \pm 0.22$ & $0.65 \pm 0.13$ \\
\hline $\mathrm{Cd}$ & $0.10 \pm 0.05$ & $0.71 \pm 0.09$ & $0.65 \pm 0.21$ & $0.90 \pm 0.25$ & $2.34 \pm 0.36$ & $0.03 \pm 0.02$ & $0.18 \pm 0.06$ & $0.85 \pm 0.24$ & $0.38 \pm 0.11$ & $0.47 \pm 0.09$ \\
\hline $\mathrm{Fe}$ & $0.01 \pm 0.02$ & $0.80 \pm 0.13$ & $0.28 \pm 0.09$ & $1.14 \pm 0.02$ & $0.03 \pm 0.02$ & $1.44 \pm 0.25$ & $0.01 \pm 0.03$ & $0.63 \pm 0.15$ & $0.43 \pm 0.18$ & $0.20 \pm 0.12$ \\
\hline As & $0.01 \pm 0.02$ & $0.56 \pm 0.15$ & $0.28 \pm 0.02$ & $0.06 \pm 0.02$ & $0.08 \pm 0.02$ & $1.07 \pm 0.22$ & $0.01 \pm 0.02$ & $0.40 \pm 014$ & $0.15 \pm 0.08$ & $0.50 \pm 0.21$ \\
\hline $\mathrm{Cu}$ & $0.12 \pm 0.04$ & $0.62 \pm 0.02$ & $0.60 \pm 0.11$ & $0.77 \pm 0.05$ & $0.70 \pm 0.18$ & $0.26 \pm 0,09$ & $0.11 \pm 0.04$ & $0.72 \pm 0.25$ & $0.17 \pm 0.07$ & $0.77 \pm 0.17$ \\
\hline Mn & $0.01 \pm 0.02$ & $0.58 \pm 0.13$ & $0.42 \pm 0.02$ & $0.46 \pm 0.02$ & $0.05 \pm 0.02$ & $4.76 \pm 0.39$ & $0.03 \pm 0.01$ & $0.55 \pm 0.13$ & $0.15 \pm 0.08$ & $0.35 \pm 0.09$ \\
\hline
\end{tabular}

by torrential rainfall, a usual phenomenon in the studied area, as dis- solved and particulate forms. In this area a natural attenuation process is taking place when the parent material is capable of buffering drain- age, being acid neutralization a primary control on the process of metal attenuation. In addition, revegetation processes are taking place in natural attenuated areas.

Obtained results suggested that $Z$. fabago could accumulate iron and A. macrostachyum iron, arsenic and manganese. The other plant species collected from the mining sites were tolerant, because their BCF and TF values were lower than unity. Although these plant species do not ac- cumulate high concentrations of trace elements, they may be a good tool for reducing erosion effects and also for reducing the leaching of metals.

\section{Acknowledgment}

The authors are grateful to the Spanish Ministerio de Ciencia e Innovación (CTM2008-18 04567).

\section{References}

Adriano, D.C., 2001. Trace elements in terrestrial environments: biogeochemistry, bio- availability and risks of metals. Springer-Verlag, New York.

AFNOR, 1993. Norme française NF X 31-109. Qualité des sols. Méthodes chimiques. Détermination du carbone organique par oxidation sulfochromique.

Antonsiewicz, D.M., Escude-Duran, C., Wierzbowska, E., Sklodowska, A., 2008. Indigenous plant species with potential for the phytoremediation of arsenic and metal contam- inated soil. Water Air and Soil Pollution 19, 197-210.

Baker, A.J.M., 1981. Accumulators and excluders: strategies in the response of plants to heavy metals. Journal of Plant Nutrition 3, 643-654.

Baker, A.J.M., Brooks, R.R., 1989. Terrestrial higher plants which hyperaccumulate me- tallic elements: a review of their distribution, ecology and phytochemistry. Biore- covery 1,811 826.

Baker, A.J.M., McGrath, S.P., Sidoli, C.M.D., Reeves, R.D., 1994. The possibility of in situ heavymetal decontamination of polluted soils using crops of metal accumulating plants. Resources Conservation Recycling 11, 41-49.

Baker, A.J.M., McGrath, S.P., Reeves, R.D., Smith, J.A.C., 2000. Metal hyperaccumulator plants: a review of the ecology and physiology of a biological resource for phytore- mediation of metalpolluted soils. In: Terry, N., Bañuelos, G. (Eds.), Phytoremediation of Contaminated Soil and Water. Lewis Publishers CRC, Boca Raton, pp. 85-107.

Bech, J., Duran, P., Roca, N., Poma, W., Sánchez, I., Barceló, J., Boluda, R., Roca-Pérez, L., Poschenrieder, C., 2012. Shoot accumulation of several trace elements in native plant species from contaminated soils in the Peruvian Andes. Journal of Geochem- ical Exploration 113, $106-111$.
Bose, S., Chandrayan, S., Rai, V., Bhatacharyya, A.K., Ramanathan, A.L., 2008. Translocation of metals in pea plants grown on various amendment of electroplating industrial sludge. Bioresource Technology 99, 4467-4475.

Brooks, R.R., Lee, J., Reeves, R.D., Jaffre, T., 1977. Detection of nickeliferous rocks by analysis of herbarium specimens of indiator plants. Journal of Geochemical Explo- ration 7, 49-57.

García-Lorenzo, M.L., Pérez-Sirvent, C., Martínez-Sánchez, M.J., Molina-Ruiz, J., 2012. Trace element contamination in an abandoned mining site in a semiarid zone. Journal of Geochemical Exploration 113, 23-35.

Gardea-Torresdey, J.L., Tiemann, K.J., Gonzales, J.H., Hennig, J.A., Townsend, M.S., 1996. Ability of silica-immobilized Medicago sativa to remove copper ions from solution. Journal of Hazardous Materials 48, 181-190.

Ha, N.T.H., Sakakibara, M., Sano, S., Nhuan, M.T., 2011. Uptake of metals and metalloids by plant growing in a lead-zinc mine area, Northern Vietnam. Journal of Hazardous Materials 186, 1384 1391.

Hernández-Allica, J., Becerril, J.M., Zarate, O., Garbisu, C., 2006. Assessment of the effi- ciency of a metal phytoextraction process with biological indicators of soil health. Plant and Soil 281, 147-158.

Kabata-Pendias, A., Mukherjee, A.B., 2007. Trace Elements from Soil to Human. Springer.

Marchiol, L., Assolari, S., Sacco, P., Zerbi, G., 2004. Phytoextraction of heavy metals by canol (Brassica napus) and radish (Raphanus sativus) grown on multicontami- nated soil. Environmental Pollution 132, 21-27.

Martín, D., 2004. Qualitative, quantitative and microtextural powder X-Ray diffraction analysis. http://www.xpowder.com last access: December 13th, 2011.

Martínez-Sánchez, M.J., Navarro, M.C., Pérez-Sirvent, C., Marimón, J., Vidal, J., García- Lorenzo M.L., Bech, J., 2008. Assessment of the mobility of metals in a mining- impacted coastal area (Spain, Western Mediterranean). Journal of Geochemical Exploration 96, 171-182.

McGrath, S.P., Zhao, F.J., 2003. Phytoextraction of metals and metalloids from contam- inated soils. Current Opinion in Biotechnology 14, 1-6.

Nelson, D.W., Sommers, L.E., 1982. Total carbon, organic carbon, and organic matter. In: Page, A.L., Miller, R.H., Keeney, D.R. (Eds.), Methods of soil analysis. Part 2. Soil Sci- ence Society of America, Madison, pp. 539-579.

Prasad, M.N., Freitas, M.H., 2003. Metal hyperaccumulation in plants-biodiversity pro- specting for phytoremediation technology. Electronic Journal of Biotechnology 6, 285-321.

Rotkittikhun, P., Kruatrachue, M., Chaiyarat, R., Ngernsansaruay, C., Pokethitiyook, P., Paijitprapaporn, Baker, A.J.M., 2006. Uptake and accumulation of lead by plants from the Bo Ngam lead mine area in Thailand. Environmental Pollution 144, 681-688.

Sun, Y., Zhou, Q., Diao, Ch., 2008. Effects of cadmium and arsenic on growth and metal accumulation of Cd-hyperaccumulator Solanum nigrum L. Bioresource Technology 99, 1103-1110.

USEPA, 2000. Introduction to phytoremediation. EPA 600/R-99/107. U.S. Environmental Protection Agency, Office of Research and Development, Cicinnati, OH.

Zhuang, P., Ye, Z.H., Lan, C.Y., Xie, Z.W., Shu, W.S., 2005. Chemically assisted phytoex- traction of heavy metal contaminated soils using three plant species. Plant and Soil 276, 153-162. 